\title{
A new occurrence of Anodontites tenebricosus (Bivalvia: Mycetopodidae) in the Sapucaí river basin, São Paulo, Brazil: environmental and conchological aspects
}

\author{
Troncon, EK.* and Avelar, WEP.* \\ Laboratório de Malacologia, Departamento de Biologia, Faculdade de Filosofia, Ciências e Letras de Ribeirão Preto, \\ Universidade de São Paulo - USP, Av. Bandeirantes, 3900, CEP 14040-901, Ribeirão Preto, SP, Brazil \\ *e-mail: elisakt@usp.br; waavelar@ffclrp.usp.br
}

Received July 7, 2010 - Accepted September 1, 2010 - Distributed - August 31, 2011

(With 6 figures)

\begin{abstract}
The aim of this work was to register the occurrence of Anodontites tenebricosus (Bivalvia: Mycetopodidae) in the Sapucaí river basin, municipality of São Joaquim da Barra, São Paulo state, Brazil, associating its occurrence to the environment in which they are found, besides providing conchological data to contribute to the identification of the species. Fifty one specimens of Anodontites tenebricosus were studied regarding their conchological and morphometrical aspects. Strong correlations were found between the morphometric variables, the correlation between 'length and height of the shell' being the most significant. The characteristics of the shells of A. tenebricosus found in the Sapucaí river basin resemble the descriptions of the species found in the literature; therefore, we are able to expand the area of occurrence of the species for the state of São Paulo.
\end{abstract}

Keywords: Bivalvia, Mycetopodidae, Anodontites tenebricosus, conchology, sedimentology.

\section{Nova ocorrência de Anodontites tenebricosus (Bivalvia: Mycetopodidae) na bacia do rio Sapucaí, São Paulo, Brasil: aspectos ambientais e conquiliológicos}

\begin{abstract}
Resumo
Os objetivos deste trabalho foram registrar a ocorrência de Anodontites tenebricosus (Bivalvia: Mycetopodidae) na bacia do rio Sapucaí, no município de São Joaquim da Barra, estado de São Paulo, Brasil, associando sua ocorrência ao ambiente em que são encontrados, além de fornecer dados conquiliológicos que contribuem para a identificação da espécie. Cinquenta e um espécimes de Anodontites tenebricosus foram estudados sob aspectos conquiliológicos e morfométricos. Foram encontradas fortes correlações entre as variáveis, sendo a correlação entre "comprimento e altura da concha" a mais significativa. As características das conchas de A. tenebricosus encontradas na bacia do rio Sapucaí assemelham-se às descrições da espécie na literatura; podemos, assim, ampliar a área de ocorrência da espécie para o estado de São Paulo.
\end{abstract}

Palavras-chave: Bivalvia, Mycetopodidae, Anodontites tenebricosus, conquiliologia, sedimentologia.

\section{Introduction}

Not a large number of limnic bivalves have been studied in the state of São Paulo and they are rarely mentioned in the literature, in spite of their importance as significant components of freshwater ecossystems, in the recycling of nutrients, and as entities capable of providing reliable evidence of pollutants in limnic watersheds (Vaughn and Taylor, 1999). However, they are the most seriously endangered group of freshwater organisms. The main causes for that include anthropogenic activities, such as building dams, pollution and toxicity of the sediment, as well as the introduction of exotic species (Bogan, 1993; Lydeard et al., 2004). Therefore, the consequences of bivalve population decline in the fauna of the rivers go beyond the loss of the species per se (Vaughn and Taylor, 1999). Since they play an important role in the functioning of lotic and lentic ecossystems, the importance of studies regarding aspects of biology, anatomy and ecology of freshwater bivalve native fauna is justified.

In Brazil, the freshwater bivalves are represented by the orders Unionoida and Veneroida. The first includes the families Mycetopodidae and Hyriidae, while the second includes the families Dreissenidae, Pisidiidae and, more recently, Corbiculidae and Mytilidae, being these latter represented, respectively, by the asiatic species Corbicula fluminea (Müller, 1774) and Limnoperna fortunei (Dunker, 1857) (Simone, 2006). 
According to Castellanos and Landoni (1990), the Mycetopodidae family (Gray, 1940) is restricted to South America, not being found in the Andean-Patagonian region, and occurs in lentic and lotic environments. They are found partially buried in sediment of variable particle sizes and they feed on particles in suspension, such as plankton and organic detritus. In Brazil, the family is represented by 12 genera and the genus Anodontites represents the largest number of species (15) (Simone, 2006).

Taking the Mycetopodidade family into consideration, the following species were registered in the state of São Paulo: Fossula fossiculifera (Orbigny, 1835) (Avelar, 1993), Anodontites trapesialis (Lamarck, 1819) (Hebling, 1976), A. trapezeus (Spix, 1827) (Hebling, 1976) and A. soleniformis (Orbigny, 1835) (Avelar and Cunha, 2001).

The aim of this study was to register the occurrence of Anodontites tenebricosus (Lea, 1834) in the Sapucaí river basin, municipality of São Joaquim da Barra, São Paulo state, Brazil, as well as to provide conchological data that contribute to the species' identification, associating its occurence with the environment in which they are found.

\section{Material and Methods}

\subsection{Study area and methodology for collecting animals}

The study was conducted in the Sapucaí river basin, municipality of São Joaquim da Barra, SP, Brazil ( $\left.20^{\circ} 30^{\prime} 49,7^{\prime \prime} \mathrm{S} ; 47^{\circ} 50^{\prime} 10,2^{\prime \prime} \mathrm{W}\right)$, which, according to data from CETESB (Companhia de Tecnologia de Saneamento Ambiental, 2007), is part of the Sapucaí/Grande basin.

The animals were collected monthly, from August 2007 to January 2008. Living specimens and valves of Anodontites tenebricosus were located in the Sapucaí river by touching the river bottom with the hands and removing rocks and pebbles while looking for the animals. When found, they were collected and taken to the laboratory in coolers containing water from the river, for conchological and morphological studies.

For the shell studies, a digital calliper was used and the following measures were taken: length (greater distance between the anterior and the posterior axis of the shell), height (distance between the ventral and dorsal axis of the shell, passing through the umbonal region), width (distance between the two valves, with the shell closed, also passing through the umbonal region) and length of the ligament. Furthermore, the correlations between the morphometric variables were examined using Pearson's Correlation Coefficient (r).

Ten specimens were deposited as vouchers in the Museum of Zoology at the University of São Paulo (MZSP 96618).

\subsection{Temperature, abiotic factors of the water and sedimentology}

Measurements of external temperature and abiotic factors of the water at the collection site on the Sapucaí river were taken monthly throughout the year, between August 2007 and July 2008. Temperature, dissolved oxygen, conductivity and turbidity of the water were considered, aiming for the determination of the association between the physical and chemical data obtained in this study.

Sediment samples from the river bottom were also collected from September 2007 to January 2008 in order to perform particle size analysis and determination of organic matter content. The sediment was placed in properly labelled plastic bags and was transported to the laboratory in ice coolers.

Portions of the collected sediment, preserved in a freezer, went through the process of drying in an oven at $60{ }^{\circ} \mathrm{C}$ to obtain the dry weight. However, the drying time of the sediment is not defined because the samples are collected from submerged surface horizon, and the quantity of water varies in each sample. After the drying process, $50 \mathrm{~g}$ of the sample were sieved and separated by the method of quartering (Muehe, 1996). According to this method, the sample is poured onto a surface forming a cone. This cone is divided into four equal parts and two parts are used, being opposite to each other. This procedure is repeated until obtaining the desired weight sample. The remaining $50 \mathrm{~g}$ are then sieved for 15 minutes on the shaker sieve, which is previously calibrated according to standard methodology. The material retained on each sieve was weighed on an electronic scale (precision $0.001 \mathrm{~g}$ ) and identified according to Wentworth's scale for particle size of sediment (Wentworth, 1922).

Quantification of organic matter present in the sediment was determined by burning $10 \mathrm{~g}$ of material in an oven at $500{ }^{\circ} \mathrm{C}$ for three hours, and the difference between the initial and final mass represents the amount of organic matter present in the sample.

\section{Results}

\subsection{Animals: morphology and morphometry of the shell}

Fifty-one specimens of Anodontites tenebricosus were sampled in the Sapucaí river (Figure 1), being most of them found in the middle of the river, within a distance of about $20 \mathrm{~m}$ from the shore. It should be pointed out that the animals were always found in areas of rapids, partially buried in the sediment, and protected by rocks and pebbles.

The shells of A. tenebricosus (Figures 2) are elliptical or reniform, thin and with a strong ventral deflexion in most of the specimens. The periostracum is dark, brownish-green, opaque and usually eroded, especially in the umbo area (u). Sculpture of the periostracum slightly checkered and it varies depending on the region of the shell (Figure 3). In the posterior dorsal region, 5 to 6 radial lines (rl), not prominent in some specimens, raise from the umbonal region toward the posterior end. The ligament (1) is long, thin, with a triangular shape ligamental sinus (ls).

The inner surface of the shell presents brown colouration, mixed with bluish-white iridescent shade. The umbonal cavity is shallow and a proeminent keel $(\mathrm{k})$ arises from this region toward the posterior region of the shell. The muscle scars are well defined: anterior addutor muscle 


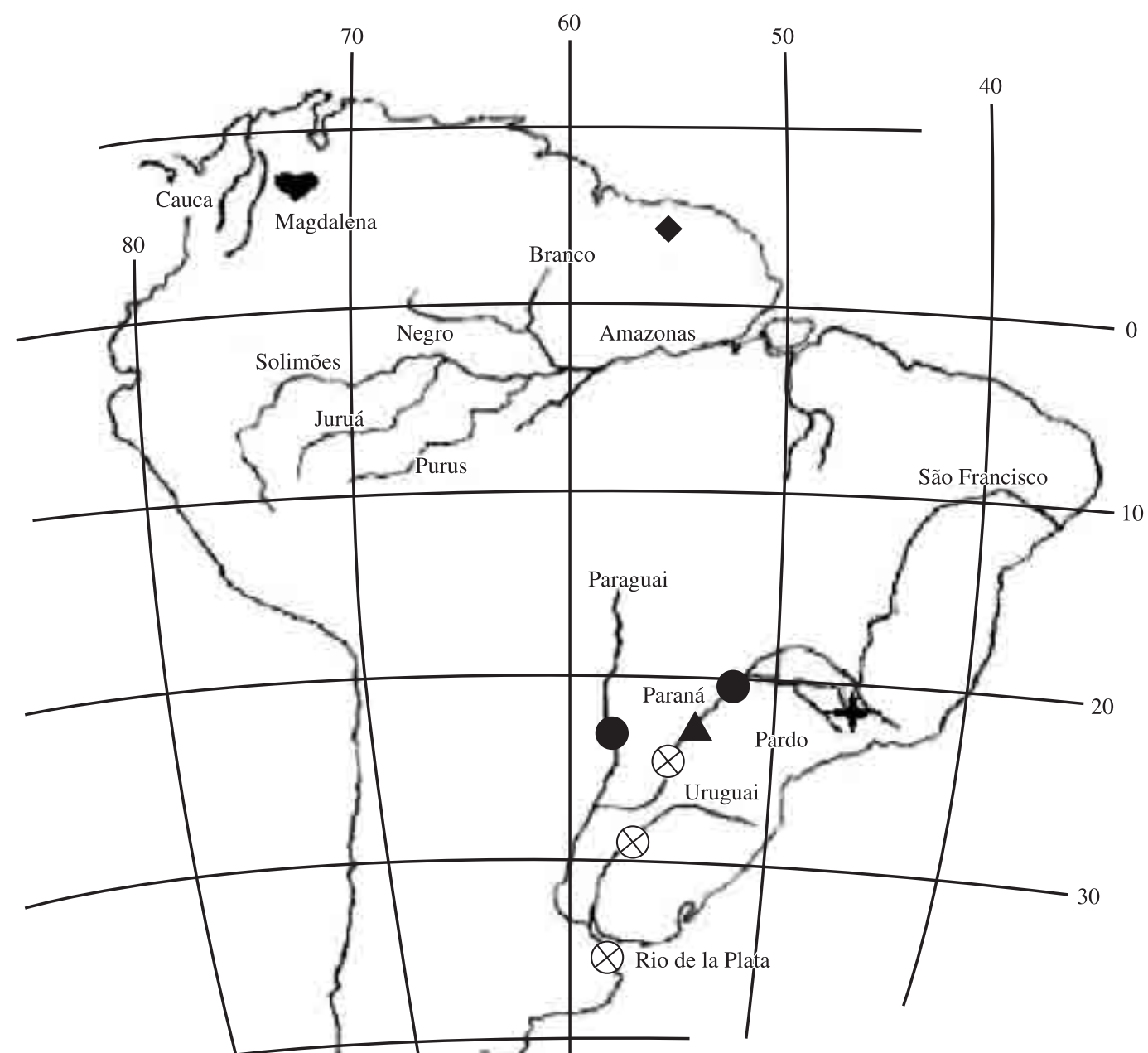

South Atlantic Ocean

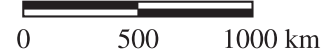

Figure 1. South American map: (†) New distribution of Anodontites tenebricosus in South America; $(\diamond)$ Type locality of A. crispata by Brugière, cited by Marshall (1931); ( $\bullet$ Type locality of A. crispata Brugière by Ortmann (1921); (A) Distribution of Anodonta tenebricosa by Lea (1834); ( $\otimes$ ) Type locality of A. crispatus tenebricosus by Bonetto and Escurra (1965); (-) Type locality of A. crispatus soleniformis by Bonetto and Escurra (1965).

scar (aam) eliptical and posterior addutor muscle scar (pam) with a round shape. Anterior retracting muscle of the foot (arm) separated from the anterior addutor muscle; posterior retracting muscle of the foot (prm) united to posterior addutor muscle. The pallial line $(\mathrm{pl})$ is distinct and is parallel to the margin of the shell (Figure 2).

Considering the morphometry of the shell, the length varied from 3.32 to $7.47 \mathrm{~cm}$, being the average length $5.84 \pm 1.0 \mathrm{~cm}$; height ranged from 1.49 to $3.08 \mathrm{~cm}$ (average:
$2.48 \pm 0.38 \mathrm{~cm}$ ); width ranged from 0.82 to $2.08 \mathrm{~cm}$ (average: $1.44 \pm 0.28 \mathrm{~cm}$ ) and the length of the ligament varied from 1.0 to $2.53 \mathrm{~cm}$, being the average value $1.87 \pm 0.36 \mathrm{~cm}$.

As for the correlations between the morphometric values, strong correlations were found (Coefficient $r>0.7$ ) between the variables: 'length and height' $\left(r^{2}=0.9258\right)$, 'length and width' $\left(r^{2}=0.777\right)$, 'height and width' $\left(r^{2}=0.8134\right)$ and 'length of the shell and length of the ligament' $\left(r^{2}=0.7167\right)$ (Figure 4). The correlation between the variables 'length 


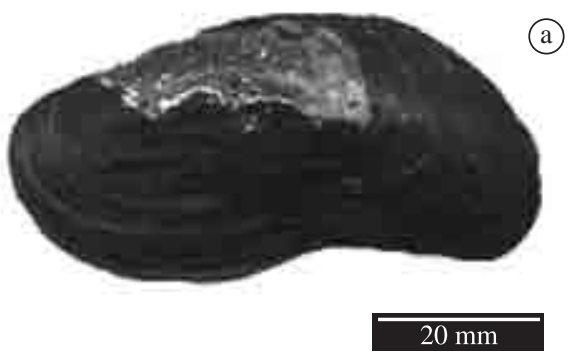

(c)
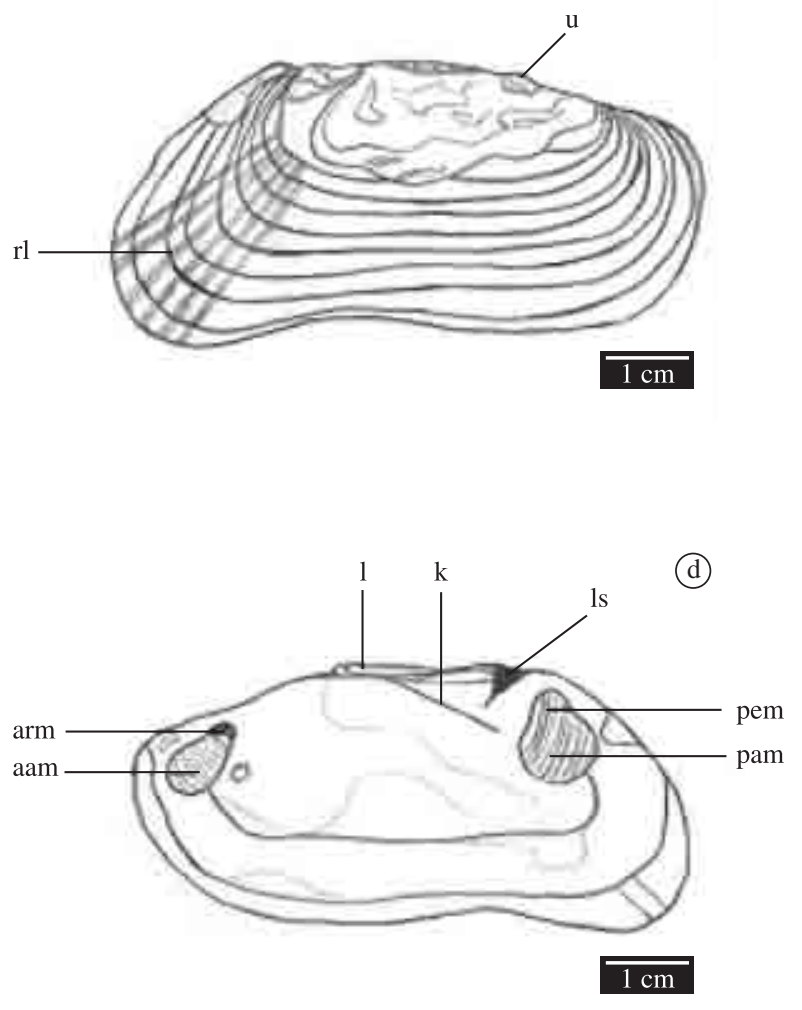

(b)

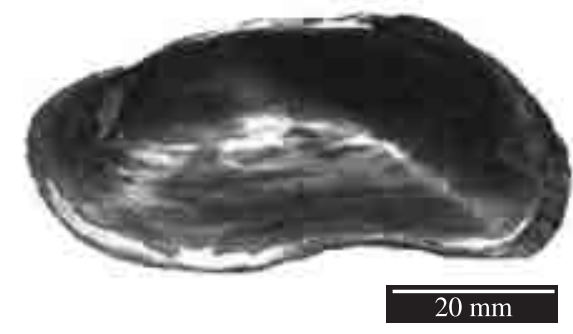

(e)
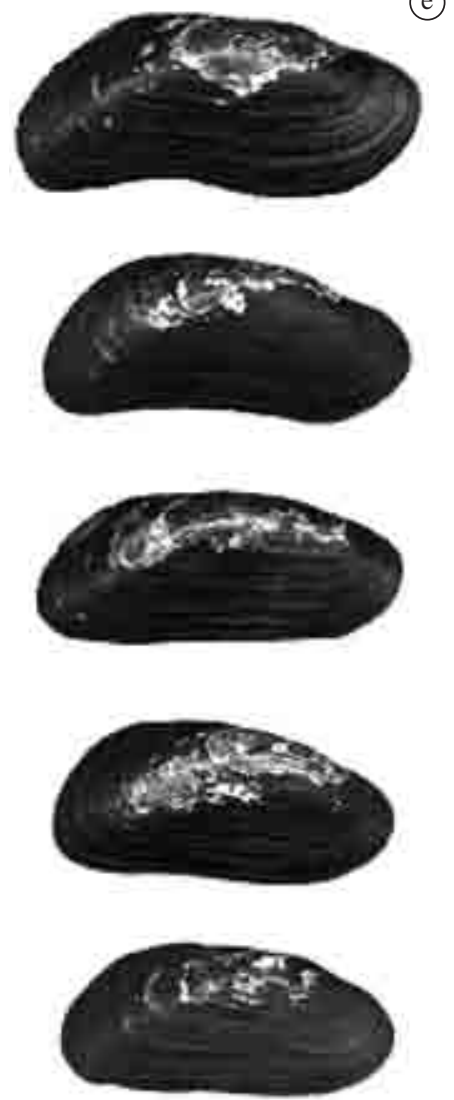

$20 \mathrm{~mm}$

Figure 2. Shells of Anodontites tenebricosus found in the Sapucaí river basin, in São Joaquim da Barra, SP, Brazil. a) External view of the left valve; b) Internal view of the right valve; c) External view of the right valve: (rl) radial lines, (u) umbo area; d) Internal view of the right valve: (aam) anterior addutor muscle scar, (arm) anterior retracting muscle of the foot scar, (k) keel, (l) ligament, (ls) ligamental sinus, (pam) posterior adductor muscle scar, (pl) palial line, (prm) posterior retracting muscle of the foot scar; and e) Different degrees of ventral deflexion.

and height' of the shell was the most significant and, on average, the height corresponds to $43 \%$ of the length of the shell.

\subsection{Temperature, abiotic factors of the water and sedimentology}

The measurements of external temperature and of the abiotic factors of the water in the study area, for each sampling month, can be found in Figure 5.
Considering the temperature, the values registered varied from 20 to $28.8^{\circ} \mathrm{C}$, being the annual average $23.7 \pm 2.52{ }^{\circ} \mathrm{C}$, while for the water temperature, the average was $22.62 \pm 2.52^{\circ} \mathrm{C}$ and the values varied between 19 and $26.4{ }^{\circ} \mathrm{C}$.

As for dissolved oxygen, the values ranged from 7.23 to $11.48 \mathrm{mg} . \mathrm{L}^{-1}$, being the annual average $9.11 \pm 1.43 \mathrm{mg} . \mathrm{L}^{-1}$. The high values registered are due to 

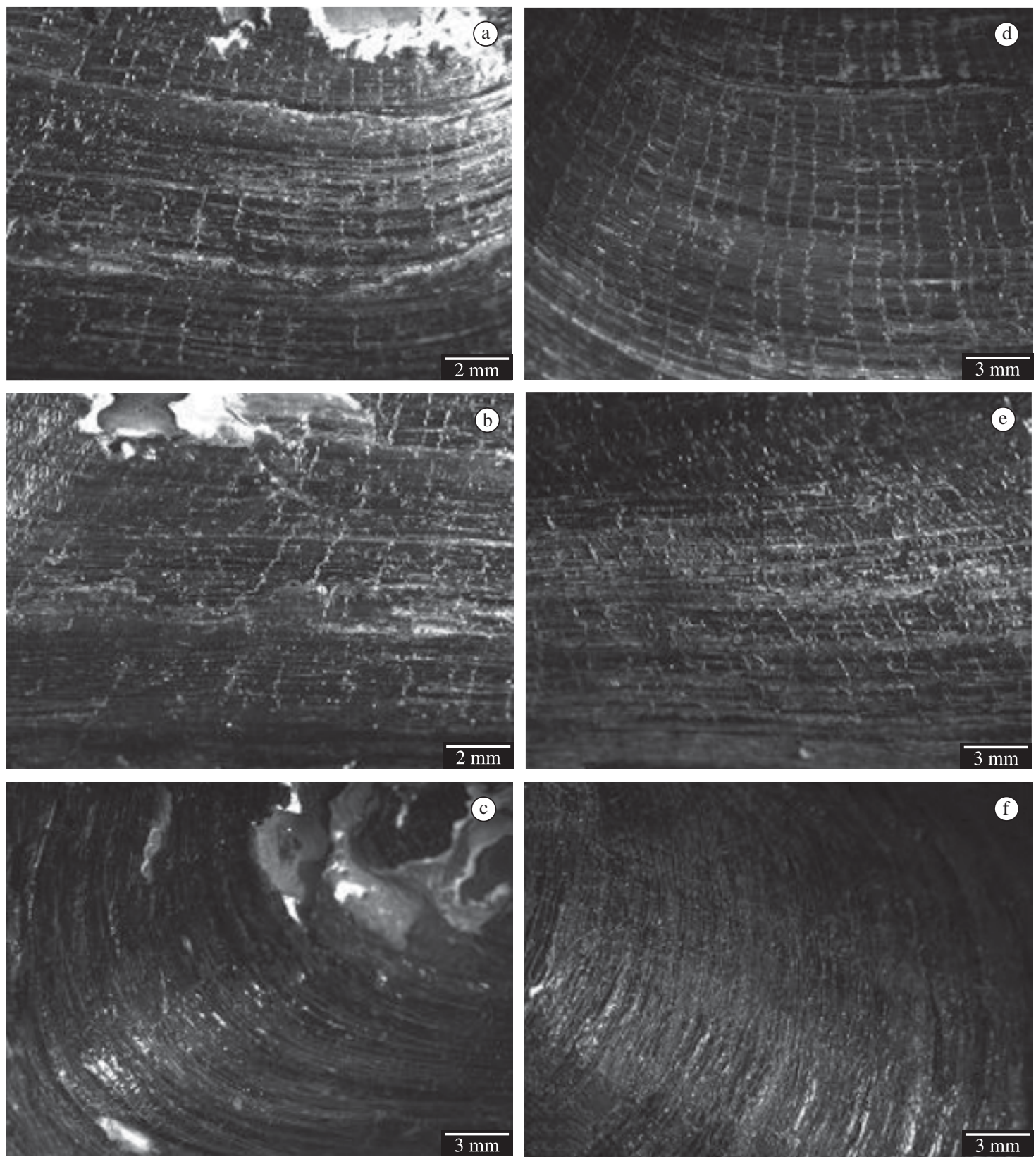

Figure 3. a-c) Sculpture of the periostracum in shells of Anodontites tenebricosus: a) Anterior, b) Medium and c) Posterior region. d-f) Sculpture of the periostracum in shells of Anodontites soleniformis: d) Anterior, e) Medium and f) Posterior region.

the fact that the river is a river of rapids and, also, because of the presence of currents at the point of study.

Regarding conductivity, the annual average registered was $54.09 \pm 11.90 \mathrm{~ms}$ and the values varied from 38.7 to $83 \mathrm{~ms}$. The highest values were registered between August and October, which can be explained by drought periods, when there is a decrease in the river levels.

Considering turbidity, the values ranged from 6.15 to $89.9 \mathrm{ntu}$, with annual average of $37.86 \pm 29.00 \mathrm{ntu}$. The highest values were registered during the flood months (maximum value registered in December 2007) which may be related to periods of rain, where there is great variation, both in the level of the river and the water speed.

As for sedimentology, the analysis showed a predominance of grains in the sediment, that is, a predominance of particles larger than $2.00 \mathrm{~mm}$, in all sampling months (Figure 6). Considering the organic matter of the sediment, October and November 2007 showed a higher percentage of organic matter, $4.4 \%$ and $4.95 \%$ respectively, when compared to other months of 

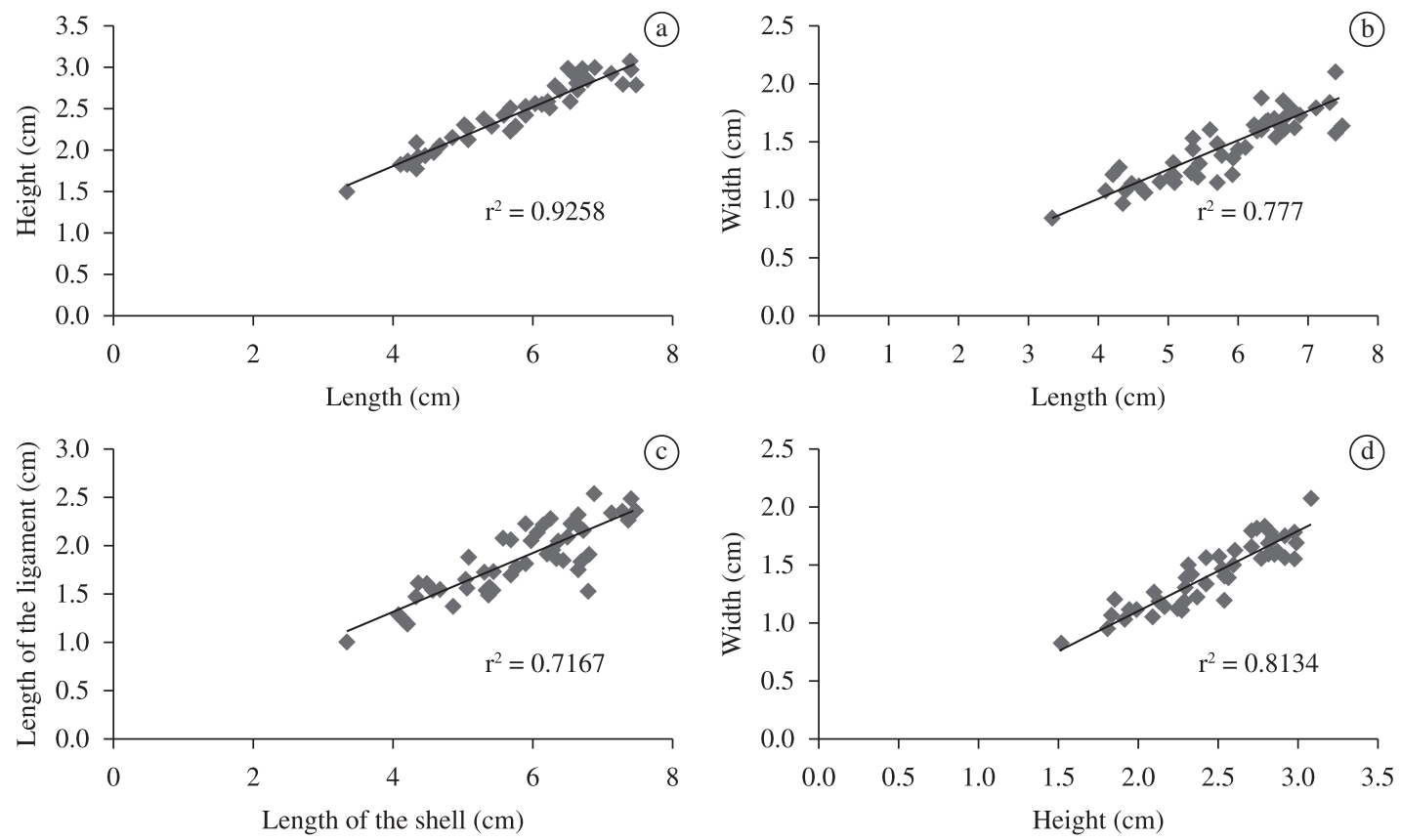

Figure 4. Correlations between the morphometric variables analysed from the shells of Anodontites tenebricosus, showing the values of Pearson's coefficient $\left(\mathrm{r}^{2}\right)$ : a) Correlation 'height and length'; b) Correlation 'width and length'; c) Correlation 'length of the ligament and length of the shell'; and d) Correlation 'height and width'.
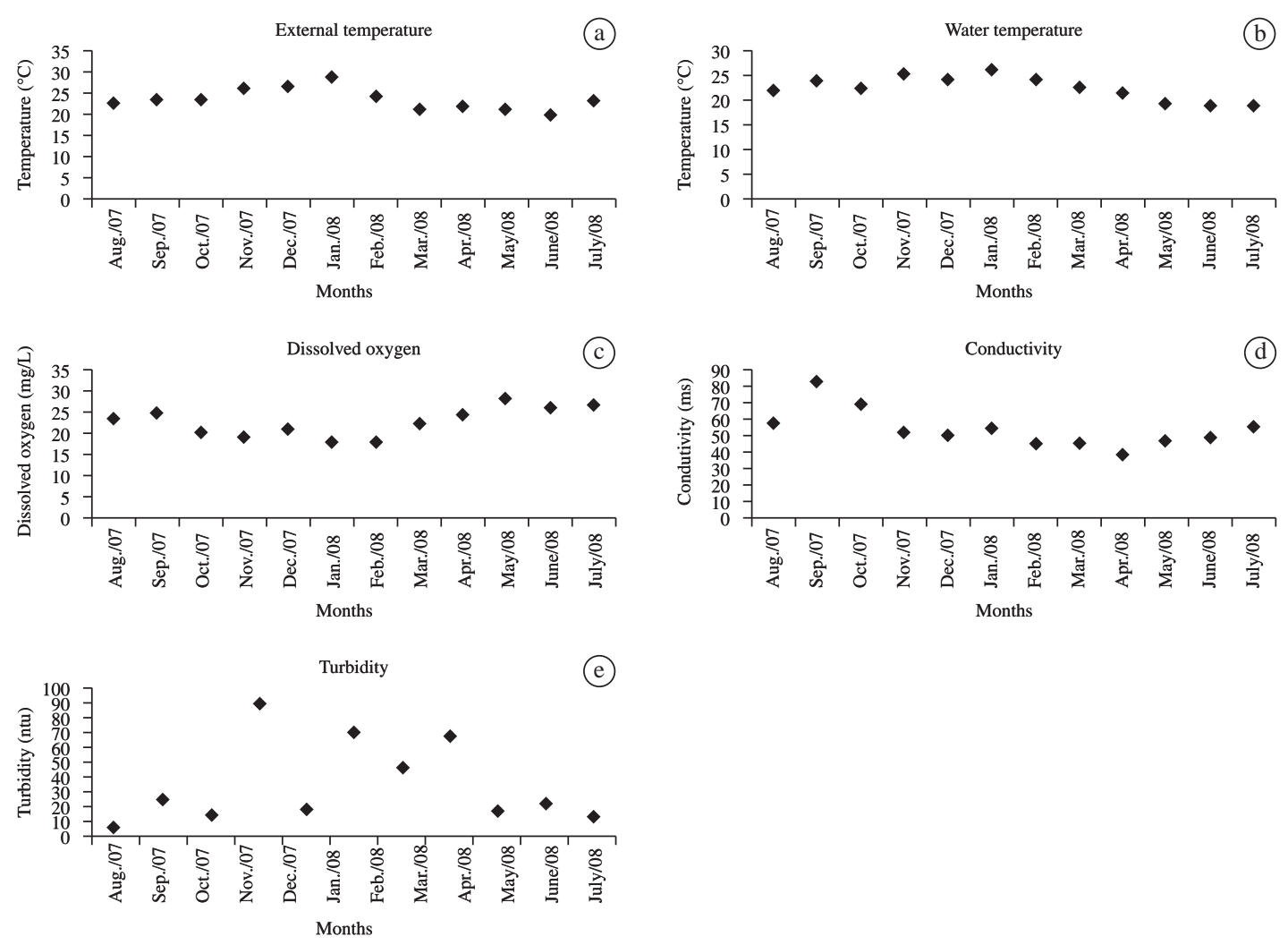

Figure 5. Monthly measurements, from August 2007 to July 2008, of temperature and abiotic factors of the water at the collection site in the Sapucaí river basin, municipality of São Joaquim da Barra, SP, Brazil: a) External temperature; b) Water temperature; c) Dissolved Oxygen; d) Conductivity; and e) Turbidity. 


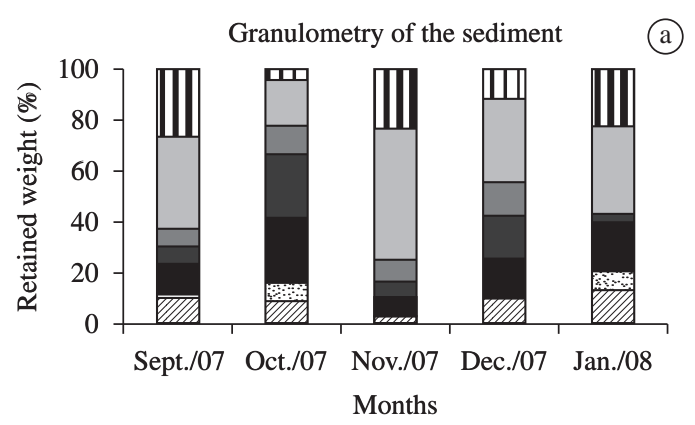

\begin{tabular}{|c|c|c|}
\hline $\begin{array}{l}\text { I Pebble } \\
\text { Medium sand } \\
\text { Silt and clay }\end{array}$ & $\begin{array}{l}\square \text { Granule } \\
\text { Thin sand }\end{array}$ & $\begin{array}{l}\text { Thick sand } \\
\text { Very thin sand }\end{array}$ \\
\hline
\end{tabular}

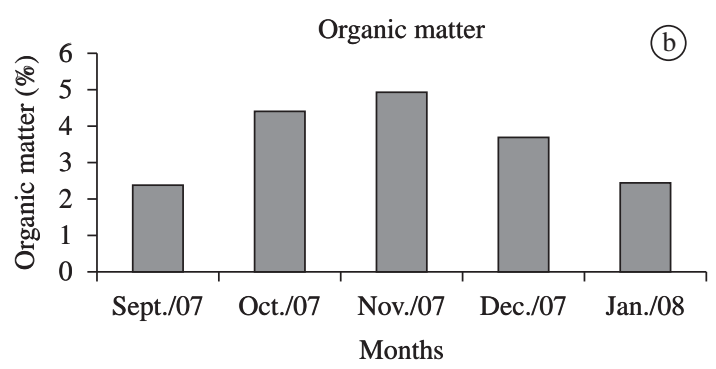

Figure 6. a) Granulometry of the sediment and b) Organic matter (\%) from the sediment collected, from September 2007 to January 2008, in the Sapucaí river basin, municipality of São Joaquim da Barra, SP, Brazil.

sampling (Figure 6). According to Moniz (1972), the low percentage found in all months analysed (less than $20 \%$ dry weight), characterises mineral sediment in the study area.

\section{Discussion}

Anodontites crispata Bruguière, 1792

Anodonta tenebricosa Lea, 1834

Anodonta soleniformis Orbigny, 1835

Anodon solenidea Sowerby, 1867

Mycetopus plicatus Clessin, 1882 (non Sowerby, 1868)

Mycetopus clessini Fischer, 1890

Glabaris soleniformis var. apae Ihering, 1893

Glabaris nehringi Ihering, 1893

Glabaris clessini: Simpson, 1900

Anodontites clessini: Simpson, 1914

Anodontites soleniformis: Haas, 1931; 1969

Anodontites (Anodontites) crispatus tenebricosus: Mansur, 1970
The genus Anodontites was described by Bruguière, in 1792, and it takes its name from the hinge of the shell, which is plain and without teeth, being very different from the hinge of other bivalve shells. Furthermore, the genus was characterised by longer than higher shells, always free of byssus and presenting three muscle scars (Marshall, 1931). According to Bonetto (1967), the genus Anodontites consists of a group of species in whose shell shape varies from oval to eliptical, with subsolid valves (in spite of being fragile for the great development of the prismatic nacreous layer), umbos a little prominent and with no sculptures.

Bruguière's description was based on A. crispata, found in the rivers of Guyana, and both its description and its figure constituted the root for further studies on edentulous naiades, especially in South America and West Africa. Due to this fact, Marshall (1931) provided a more detailed description of the species, as well as a description of its larva (lasidium).

Marshall (1931) also tried to correct the mistakes related to the genus Anodontites and to the species A. crispata, in an attempt to provide a historical record and make the study of South American bivalves easier. According to the author, from the beginning, both genus and species were subjected to many errors, being the fact that the division of the edentulous naiades into genus depended just on conchological characters. Thus, when comparing various descriptions, the description of a genus often fitted into one or several others (Marshall, 1931).

The object of this study, Anodontites tenebricosus, was first described by Lea (1834) as Anodonta tenebricosa, inhabitant of Paraná river, in South America. However, as shown in the synonymic list, based on the work of several authors such as Bonetto (1967), Mansur and Pereira (2006) and Simone (2006), A. tenebricosus has already been considered as a synonym of $A$. crispata, as well as belonging to the genera Anodonta, Anodon, Mycetopus and Glabaris. Nevertheless, according to Marshall (1931), its features were so different from those of A. crispata that the two could not be members of the same group of Anodontites.

Bonetto and Ezcurra (1965), studying the sculptures of the periostracum of species from the genus Anodontites, grouped A. tenebricosus with A. soleniformis (Orbigny, 1835), gathering both species as a subspecies of Anodontites crispata Bruguière, and set the following areas of occurrence: Inferior Paraná, La Plata and Uruguay rivers for A. crispatus tenebricosus, and High Paraná and Paraguay for A. crispatus soleniformis. However, according to Bonetto (1967), with the investigation of several animals from the upper sections of Medium Paraná, High Paraná, Paraguay and coast rivers of Brazil, the animals considered by Bonetto and Ezcurra (1965) such as A. soleniformis, perfectly corresponded to the type A. tenebricosus. Therefore, Bonetto (1967) places A. soleniformis as a synonym of Anodontites crispatus tenebricosus, and describes this subspecies, differentiating it from A. crispatus crispatus. As stated by the author, this species extends to all river basins from La Plata river 
system, in Argentina, including High Paraná, and coastal rivers from Brazil until São Francisco basin.

Mansur (1970) considers Anodontites crispatus tenebricosus as a synonym of Anodontites tenebricosus sensu Lea (1834). However, the author considers A. crispatus soleniformis as a distinct subspecies for the Paraná river.

Mansur and Silva (1990) provided a description of the shell and of the soft parts of A. tenebricosus, found in the Uruguay and Amazon river basins, and compared this species with Bartlettia stefanensis (Moricand, 1856) found in the Amazon basin.

Simone (2006) does not recognise the species described by Bonetto (1967) and considers two distinct species: Anodontites crispatus (Bruguière, 1792), with restricted distribution in the Amazon region, Guyana, Equator and Peru, and A. tenebricosus (Lea, 1834), as a synonym of A. soleniformis, with distribution in South American river basins west of the Andes.

Mansur and Pereira (2006) also consider A. soleniformis as a synonym of $A$. tenebricosus sensu Lea (1834) and provided a brief description of the animals' shells.

In relation to the morphometric measures of the shells, the average value for length of the shell and length of the ligament in the present study are slightly different from those found by Mansur and Silva (1990) and Mansur and Pereira (2006). However, the average value for height of the shell resembles those found by the same authors.

It should be pointed out that there may be some difficulties in the identification of native bivalves because of the existence of several species in which the shells are very similar; nevertheless, in some cases, this similarity may be due to ecological variance (Bonetto, 1965). Thus, the classification of freshwater bivalves, in generic and specific levels, is rather problematic. Several names were given to these animals and some classifications present dozens of different synonyms. This confusion is partly attributed to amateur collectors and partly to the fact that old classifications are based on characteristics of the shell, instead of anatomical features (Mansur, 1970).

According to Bonetto (1967), there is a lack of determinant conchiological characters, and the great number of imprecise descriptions with no objectives and informative values seems to be general to all naiades in the world. Besides, almost all bivalve species occupy a great territorial extension, which makes the precise identification of the animals even more difficult. In this manner, Simone (1994) shows the importance of anatomical studies to achieve a greater precision in identifying species, indicating that these studies may also collaborate with phylogenetic analysis.

In spite of these difficulties, we may notice that the characteristics of the animals' shell found in the Sapucaí river basin, São Paulo state, resemble the descriptions of A. tenebricosus studied by Bonetto (1967) and the sculptures of the periostracum are similar to those described by Bonetto and Ezcurra (1965). It is also worth mentioning that the sculptures of $A$. tenebricosus resemble those of A. soleniformis and are different from those of A. colombiensis and A. crispata illustrated by Avelar and Cunha (2001). Mansur and Silva (1990) and Mansur and Pereira (2006) did not mention the sculptures of the periostracum, as well as the radial lines in the posterior region of the valves.

As for the environment, Castellanos and Landoni (1990), indicate the occurrence of A. tenebricosus in clear, fast water, on sandy and very rocky bottom. In the present study, the animals were also found in very rough waters, in areas of rapids and rocky bottom. Moreover, the granulometry of the sediment showed a preference of the animals for a coarse substratum, with a predominance of large particles.

Finally, in relation to temperature and abiotic factors of the water, the variations found throughout the year of sampling are the consequences of the different seasons and periods of rain and drought, where there are variations in the river level. Therefore, the highest temperatures were found during the summer months, the highest conductivity values were found in the dry seasons (from August to October), when there is a decrease in the river level, and the highest turbidity values were found in the flood months (maximum value found in December 2007), which may be associated with periods of rain, where there are large variations in the river level and in the water speed. The highest levels of dissolved oxygen can also be explained by the presence of currents in this study area.

In conclusion, the characteristics of the shell and the sculptures of the periostracum in specimens of Anodontites tenebricosus, found in the Sapucaí river, are in accordance with the data found for this species in recent literature. Furthermore, the studies of the periostracum showed a great similarity between A. tenebricosus and A. soleniformis, reinforcing the idea that these species might be considered as A. tenebricosus sensu Lea, 1834. Considering this, our findings contribute to the notion that the area of occurrence of this species could be expanded also to the state of São Paulo.

Acknowledgements - We are grateful to CAPES and the Faculdade de Filosofia, Ciências e Letras de Ribeirão Preto, Universidade de São Paulo, for financial support, and to Mr. Álvaro da Silva Costa for assistance with the fieldwork.

\section{References}

AVELAR, WEP. 1993. Functional anatomy of Fossula fossiculifera (D’Orbigny, 1843) (Bivalvia: Mycetopodidae). American Malacological Bulletin, vol. 10, no. 2, p. 129-138.

AVELAR, WEP. and CUNHA, AD., 2001. A new occurrence of Anodontites soleniformis Orbigny, 1835 in northeastern São Paulo State, Brazil (Bivalvia:Mycetopodidae). American Malacological Bulletin, vol. 16, no. 1/2, p. 137-140.

BOGAN, AE, 1993. Freshwater bivalve extinctions (Mollusca: Unionoida): a search for causes. American Zoologist, vol. 33, no. 6, p. 599-609.

BONETTO, AA., 1965. Las especies del genero Diplodon en el sistema hidrografico del rio de La Plata (Mollusca, Unionidae). Anais do II Congresso Latino-Americano de Zoologia (São Paulo), vol. 2, p. 37-54. 
-, 1967. El género Anodontites Bruguière (Mollusca, Pelecypoda) en el sistema hidrográfico Del Plata. Physis, vol. 26, no. 73, p. 459-467.

BONETTO, AA. and EZCURRA, ID. 1965. Notas Malacologicas III. 5) La escultura del periostraco en el genero Anodontites, 6) El lasidium de Anodontites trapezeus (Spix), 7) El lasidium de Mycetopoda siliquosa (Spix). Physis, vol. 25, no. 69, p. 197-204.

CASTELLANOS, ZA. and LANDONI, N., 1990. La família Mycetopodidae Gray, 1840 em la Republica Argentina. In RINGUELET, RA. (Ed.). Fauna de água dulce de la Republica Argentina. Buenos Aires: FECIC. 86 p. vol. 16.

Companhia de Tecnologia de Saneamento Ambiental CETESB, 2007. Relatório de qualidade das águas interiores do Estado de São Paulo. CETESB.

HEBLING, NJ., 1976. The functional morphology of Anodontites trapezeus (Spix) and Anodontites trapesialis (Lamarck) (Bivalvia: Mycetopodidae). Boletim de Zoologia da Universidade de São Paulo, vol. 1, p. 265-298.

LEA, I., 1834. Observations on the Genus Unio Vol. II. Philadelphia: James Kay, Jun. and Co. 232 p.

LYDEARD, C., COWIE, RH., PONDER, WF., BOGAN, AE., BOUCHET, P., CLARK, SA., CUMMINGS, KS., FREST, TJ., GARGOMINY, O., HERBERT, DG., HERSHLER, R., PEREZ, KE., ROTH, B., SEDDON, M., STRONG, EE. and THOMPSON, FG., 2004. The global decline of nonmarine mollusks. BioScience, vol. 54, no. 4, p. 321-329. http://dx.doi. org/10.1641/0006-3568(2004)054[0321:TGDONM]2.0.CO;2

MANSUR, MCD., 1970. Lista dos moluscos bivalves das famílias Hyriidae e Mycetopodidae para o Estado do Rio Grande do Sul. Iheringia, Série Zoologia, no. 39, p. 33-95.
MANSUR, MCD. and PEREIRA, D., 2006. Bivalves límnicos da bacia do rio dos Sinos, Rio Grande do Sul (Bivalvia, Unionoida, Veneroida e Mytiloida). Revista Brasileira de Zoologia, vol. 23, no. 4, p. 1123-1147.

MANSUR, MCD. and SILVA, MGO., 1990. Morfologia e microanatomia comparada de Bartlettia stefanensis (Moricand, 1856) e Anodontites tenebricosus (Lea, 1834) (Bivalvia, Unionoida, Muteloidea). Amazoniana, vol. 11, no. 2, p. 147-166.

MARSHALL, WB., 1931. Anodontites: A genus of South and Central American and Mexican pearly fresh-water mussels. Proceedings of the United States National Museum, vol. 79, p. 1-16, pls. 1,2 .

MONIZ, AC., 1972. Elementos de pedologia. São Paulo: Editora Polígono. p.11-111. cap. 01.

MUEHE, D., 1996. Geormorfologia Costeira. In CUNHA, SB. and GUERRA, AJT. Geomorfologia: exercícios, técnicas e aplicações. Rio de Janeiro: Bertrand Brasil. p. 191-238. cap. 6.

SIMONE, LRL., 1994. Anatomical characters and systematics of Anodontites trapesialis (Lamarck, 1819) from South America (Mollusca, Bivalvia, Unionoida, Muteloida). Studies on Neotropical Fauna and Environment, vol. 29, no. 3, p. 169-185. http://dx.doi. org/10.1080/01650529409360929

-, 2006. Land and Freshwater Molluscs of Brazil. São Paulo: EGB, Fapesp. 390 p.

VAUGHN, CC. and TAYLOR, CM., 1999. Impoundments and the decline of freshwater mussels: a case study of an extinction gradient. Conservation Biology, vol. 13, no. 4, p. 912-920. http:// dx.doi.org/10.1046/j.1523-1739.1999.97343.x

WENTWORTH, CK., 1922. A scale of grade terms for clastic sediments. Journal of Geology, vol. 130, p. 337-392. 
